\title{
Perbandingan Sistem Hukum Antara Indonesia dan Malaysia
}

\author{
Sigit Somadiyono \\ Magister Hukum, Universitas Batanghari Jambi \\ J1. Slamet Riyadi, Broni, Jambi- Indonesia Tel / Faks: 0741-65351, \\ Correspondence email: sigit.somadiyono@unbari.ac.id
}

\begin{abstract}
Abstrak. Penelitian ini adalah studi perbandingan tentang dua hukum di dunia, hukum Indonesia dan hukum Malaysia. Studi keduanya dilakukan dengan membandingkan ketentuan definisi, karakteristik, tujuan, dan sistem hukum dalam struktur peradilan. Penelitian ini bertujuan untuk melihat perbandingan keduanya untuk menemukan kemungkinan adanya keunggulan dan kekurangan. Dengan melakukan perbandingan sistem hukum Malaysia, faktanya, Indonesia tidak lebih buruk dari pada di Malaysia, didalam penelitian ini ternyata Indonesia memiliki banyak keunggulan yaitu orang yang bekerja dan berprofesi di bidang hukum, dan oleh karena itu kemungkinan aturan hukum di Indonesia masih lebih baik karena banyak orang yang taat hukum. Negara Indonesia harus menciptakan sistem hukum yang baik, struktur pengadilan harus mempertimbangkan budaya masyarakat seperti Malaysia, karena penegakan hukum akan lebih efektif apabila sesuai dengan nilai atau adat istiadat yang telah terbentuk pada masyarakat itu sendiri.
\end{abstract}

Kata kunci: Hukum Komparatif; Indonesia, Malaysia; Sistem Hukum; Pengadilan

\begin{abstract}
This research is a comparative study of two laws in the world, Indonesian law and Malaysian law. The second study was conducted by comparing the terms of definition, characteristics, objectives, and legal system in the judicial structure. The study aims to look at comparisons of the two to find possible advantages and disadvantages. By comparatively comparative malaysian legal system, in fact, Indonesia is no worse than in Malaysia, in this study it turns out that Indonesia has many advantages that people who work and work in the field of law, and therefore the possibility of the rule of law in Indonesia is still better because many people are law-abiding. The State of Indonesia must create a good legal system, the structure of the court should consider the culture of society such as Malaysia, because law enforcement will be more effective when in accordance with the values or customs that have been formed in the society itself.
\end{abstract}

Keywords: Comparative Law; Indonesia, Malaysia; Legal System; Court

\section{PENDAHULUAN}

Keadilan adalah salah satu dari beberapa permasalahan penting bagi suatu negara. Masalah Keadilan akan selalu menjadikan perdebatan antar para ahli hukum bagaimana menuangkan keadilan pada suatu peraturan perundang-undangan di suatu negara. Apalagi terdapat banyak perbedaan sistem hukum di dunia seperti sistem hukum islamic Law, Common Law, Civil Law dan sebagainya yang menyebabkan semakin kompleksnya perbedaan definisi rasa keadilan. ${ }^{1}$ Peraturan perundang-undangan harus dapat mencerminkan nilai-nilai keadilan yang ada di dalam masyarakat. Produk hukum yang di buat jangan sampai menjadi sebuah peraturan yang ada tapi tidak dapat dilaksakan karena peraturan tersebut tidak melidungi kesejahteraan rakyat dan terutama tidak memberikan manfaat apapun. Namun baik dari semua undang-undang yang dibuat dalam suatu negara bermaksud untuk memastikan keselamatan orang dan mengarah pada kesejahteraan rakyat. Oleh karena itu harus ada pihak yang mengambil keputusan berdasarkan undang-undang dapat memaksa orang untuk mematuhi semua peraturan negara, dan sebagai forum di mana penduduk dapat mencari keadilan dan penyelesaian masalah-masalah hak dan kewajiban sesuai dengan hukum.

Di negara Indonesia untuk mewujudkan keadilan didirikan peradilan. Badan peradilan diciptakan dan difungsikan untuk menyelesaikan permasalah hukum yang terjadi menurut pembagian otoritas atau kekuasaanya. ${ }^{2}$ Definisi keadilan berdasarkan kamus bahas Indonesia adalah tentang litigasi. Nasional adalah sifat kebangsaan yang berasal dari bangsa itu sendiri. Dengan demikian, peradilan nasional adalah segala sesuatu tentang perkara pengadilan yang bersifat nasional atau segala sesuatu tentang perkara hukum yang mencakup suatu bangsa.

Sistem hukum dan peradilan negara Indonesia terbentuk berdasarkan Pancasila dan Undang-Undang Dasar 1945. Cita-cita pendiri bangsa Indonesia untuk mewujudkan keadilan bagi seluruh rakyat Indonesia telah jelas tercantum pada Pancasila. Sedangkan Keadilan nasional berdasarkan konstitusi berada pada Pasal 24 dan Pasal 25

${ }^{1}$ Sigit Somadiyono, Perbandingan Sejarah Positivisme Hukum Di Indonesia Sebagai Penentu Politik Hukum Dimasa Yang Akan Datang. Legalitas: Jurnal Hukum, 12(1), Juni 2020, 13-26.

${ }^{2}$ Penyelesaian sengketa dapar dilakukan melalui 2 (dua) cara yaitu litigasi didalam pengadilan atau non litigasi (diluar pengadilan). Lihat : Sigit Somadiyono, Peran Kantor Wilayah Provinsi Jambi dalam Penyelesaian Sengketa Pertanahan Melakui Mekanisme Mediasi, Wajah Hukum Volume 1 Nomor 1, Oktober 2017. 
Undang-Undang Dasar 1945 untuk menyelenggarakan peradilan yamg bertujuan menegakkan hukum dan keadilan serta menjadi kekuatan peradilan yang merdeka tanpa intervensi dari pihak manapun.

Pembagian hukum yang berlaku di dunia terbagi menjadi 2 (dua) bagian, yaitu sistem hukum umum dan sistem hukum perdata, yang keduanya memiliki karakteristik yang berbeda. Mengingat perbedaan-perbedaan ini akan memuncul metode perbandingan sistem hukum umum dan sistem hukum perdata. Metode perbandingan sistem hukum umum dan sistem hukum perdata memiliki beberapa tujuan yaitu untuk menemukan jawaban yang tepat atas masalahmasalah konkret ketika perbedaan dalam sistem hukum di berbagai negara dan masyarakat yang sebenarnya memiliki tujuan yang sama yaitu untuk menciptakan ketertiban dan kedamaian kepada setiap masyarakat di suatu negara.

Sinzheimer dalam teorinya menyampaikan bahwa hukum tidak bergerak dalam ruang hampa dan berhadapan dengan hal-hal yang abstrak tetapi, ia selalu berada dalam tatanan sosial dan hidup. ${ }^{3}$ Sehingga penting menggunakan ilmu selain dan apalagi ilmu hukum untuk menjawab permasalahan hukum yang kemudian membandingkan antar negara yang berdasarkan perbedaan sistem hukum, dan metode tersebut tidak menjadi permasalahan jika itu bisa mewujudkan keadilan bagi masyarakat.

Dalam sistem hukum Indonesia masih mayoritas dipengaruhi hukum modern yang dibawa oleh negara-negara Eropa, seperti mewarnai hukum yang hidup di Indonesia, hukum Indonesia yang kekeluargaan ini memiliki kecenderungan memprioritaskan bentuk daripada konten, sehingga tidak terlalu mempedulikan dengan isi moralitas. dan isu terkait ketimpangan pada nilai kemanusiaan yang ada dalam sistem hukum. Berdasarkan karakteristik seperti itu negara hukum menjadi sama seperti hanya pembuat peraturan perundang-undangan saja; kualitas sebuah peraturan perundang-undangan hanya ditentukan oleh kurangnya kepatuhan pada hukum.

Selama beberapa dekade sebagai negara merdeka dan berdaulat negara, Indonesia masih banyak oknum yang melakukan perbuatan curang dan kotor dalam penegakan hukum, kemungkinan adanya sistem hukum yang cacat di Indonesia selalu ada, oleh karena itu diharapkan dengan sistem hukum komparatif antara Malaysia dan Indonesia. Diharapkan dapat berkontribusi perbaikan penyempurnaan sistem hukum yang saat ini menjadi tolok ukur ketertiban negara Indonesia.

Penelitian ini berfokus pada kondisi institusi yang melayani keadilan hukum yang berlaku di Indonesia dan Malaysia. Dalam struktur masyarakat yang majemuk dari sisi agama dan perkembangan hukum adat yang telah berjalan ternyata menimbulkan perbedaan dari lembaga pencipta keadilan. Munculnya lembaga peradilan yang berbeda bisa diakibatkan pengaruh masa kolonial dan/atau kecukupan dalam memenuhi rasa keadilan masyarakatnya.

\section{METODE}

Jenis penelitian dalam jurnal ini adalah menggunakan metode penelitian hukum normatif. Penelitian normatif oleh Ronald Dworkin juga disebut studi doktrinal (doctrinal research), sebuah studi yang menganalisis baik hukum sebagai hukum seperti yang tertulis dalam buku, maupun hukum sebagai hukum oleh hakim melalui proses peradilan.

Pada penelitian hukum normatif, bahan pustaka yang merupakan data dasar dalam ilmu penelitian diklasifikasikan sebagai data sekunder. Data yang digunakan dalam penelitian ini adalah sebagai berikut:

1. Bahan hukum utama yaitu bahan hukum yang terdiri dari undang-undang yang terdiri dari peraturan perundangundang yang berkaitan dengan sistem hukum dan struktur peradilan di Indonesia dan Malaysia.

2. Bahan hukum sekunder adalah buku-buku yang ditulis oleh para ahli hukum, jurnal hukum, dan pendapat para sarjana hukum dan hasil simposium hukum termasuk prosiding hukum.

3. bahan hukum tersier terdiri atas bahan hukum yang memberikan instruksi atau penjelasan tentang bahan hukum primer dan hukum sekunder seperti kamus hukum, ensiklopedia hukum, surat kabar dan majalah yang berisi tentang topik yang relevan dalam penelitian ini.

Teknik yang digunakan untuk pengumpulan data dalam penelitian ini menggunakan metode penelitian keperpustakaan (Library Research). Studi dokumen dilakukan dengan metode inventarisasi dari berbagai bahan hukum baik bahan hukum primer maupun sekunder serta tersier melalui pencarian literatur (studi pustaka).

\section{HASIL DAN PEMBAHASAN Hukum Komparatif}

Setiap subjek hukum yang berkaitan dengan bagian spesifik dari sistem hukum, aturan hukum pidana mengatur tentang kejahatan, aturan hukum acara mengaturan tata cara dan proses persidangan. Sebagian besar yurisprudensi memiliki sifat berbeda disebabkan karena berkaitan dengan beberapa masalah yang mempengaruhi keseluruhan atau hampir semua sistem hukum di dunia. Kelompok ini termasuk subyek teoretis, antara lain sejarah hukum, sosiologi hukum, yurisprudensi dan hukum komparatif. Istilah hukum komparatif dalam berbagai bahasa antara lain:

Hukum Komparatif, Yurisprudensi Komparatif, Hukum Asing, Bandingkan Droit, Rechtsgelijking. Dalam Blacks Law Dictionary berpendapat bahwa, Yurisprudensi Komparatif adalah studi tentang prinsip hukum dengan

${ }^{3}$ Lihat : Esmi Warasih, Pranata Hukum : Sebuah Telaah Sosiologis, (Semarang: Suryandaru Utama, 2005), hlm. 3. 
melakukan perbandingan berbagai macam sistem hukum. Istilah hukum komparatif yang berbeda di atas, beberapa sarjana berpendapat bahwa membedakan istilah antara Hukum Komparatif dengan Hukum Asing sebagai berikut:

1. Hukum Komparatif, yaitu, metode untuk membandingkan sistem hukum asing dengan maksud untuk mempelajari kelebihan dan kelemahannya;

2. Hukum Asing, yaitu, belajar hukum asing dengan tujuan tunggal untuk sekedar mengetahui dan memahami sistem hukum asing itu sendiri tanpa niat nyata untuk membandingkannya dengan sistem hukum lainnya.

Komparatif hukum menurut Rudolf D. Schlesinger dalam bukunya yang berjudul Comparative Law-Cases and Materials sebagai berikut: ${ }^{4}$

1. Hukum Komparatif adalah metode untuk melakukan investigasi agar memperoleh pengetahuan dan informasi yang lebih dalam tentang materi hukum yang berbeda.

2. Hukum Komparatif bukan seperangkat aturan dan prinsip hukum, bukan cabang hukum.

3. Hukum Komparatif adalah teknik atau cara bekerja pada elemen aktual hukum asing dalam masalah hukum.

Hukum komparatif sebagai sebuah pendekatan menyiratkan untuk lebih memahami objek atau masalah yang diteliti lebih dalam dan terukur. Atas dasar itu, para sarjana menggunakan istilah metode hukum komparatif bukan dengan istilah hukum studi banding untuk menetapkan tata cara atau metode dalam melakukan pekerjaan penelitian komparatif.

Komparatif dibuat untuk masing-masing elemen atau kumulatif, dan juga dapat dilakukan pada berbagai sistem atau sub-sistem hukum yang berlaku di negara lain atau secara lintas-sektoral dengan berbagai sistem hukum kelompok masyarakat yang berbeda.

Berdasarkan pendapat dari berbagai definisi di atas, hukum komparatif adalah proses untuk mencari dan menggali serta menyelaraskan bentuk hukum berdasarkan pendekatan kegunaan dan kemanfaatan serta menyelesaian masalah termasuk unsur-unsur dan persamaan dan perbedaan dalam perbandingan hukum.

\section{Sistem Hukum}

Sistem hukum menurut Lawrence M. Friedman adalah sistem yang terdiri dari struktur, substansi dan budaya. Struktur hukum adalah elemen dasar dan nyata dari sistem hukum, polisi, jaksa, dan pengadilan serta orang-orang beserta tingkatan yang terlibat pada prosesnya. Pada substansi hukum merupakan satu elemen lain yaitu aturan bersama dengan ketentuan tentang bagaimana institusi harus bersikap. Sedangkan Budaya hukum berisikan sikap dan nilai sosial yang hidup dimasyarakat dan tidak secara langsung menggerakkan sistem hukum. Budaya hukum dari sistem hukum adalah aturan dasar untuk sistem peradilan pidana, yaitu sistem kontrol kejahatan yang terdiri dari institusi polisi, jaksa penuntut, pengadilan dan lembaga pemasyarakatan. Sistem pengendalian kejahatan di Indonesia, selain mengandalkan fasilitas, infrastruktur dan sumber daya manusia juga masih tergantung pada nilai-nilai dan pandangan tentang kehidupan dan budaya hukum masyarakat dan keanekaragaman budaya bangsa.

Perkembangan dan corak dari sistem peradilan disuatu negara dapat dilihat dari 2 (dua) sudut. Pertama, segala sesuatu berkaitan dengan administrasi peradilan. Di sini, sistem peradilan akan mencakup kelembagaan, sumber daya, tata cara, infrastruktur dan fasilitas, dan lainnya-lainnya. Kedua, sistem peradilan didefinisikan sebagai hakim yang bertugas dan berperan sebagai pemerilsa dan pemutus kasus.

\section{Keadilan Institusional}

Lembaga peradilan dapat dibedakan antara pengaturan horisontal dan vertikal. ${ }^{5}$ Komposisi berbagai masalah lingkungan badan peradilan horisontal (pengadilan umum, pengadilan agama, pengadilan militer, pengadilan administrasi dan pengadilan pajak). Ada juga badan peradilan khusus di pengadilan umum dan Mahkamah Konstitusi. Khusus untuk wilayah Aceh terdapat juga Pengadilan Syariah Kabupate/kota dan Pengadilan Syariah Provinsi.

Pengaturan pengadilan vertikal adalah pengaturan yang mengatur dari tingkat pertama, banding dan kasasi. Terhadap pengaturan horizontal ditemukan diharapkan akan muncul lingkungan baru dalam sistem peradilan baik secara mandiri atau yang berada di lingkungan masyarakat yang telah ada dan hidup.

Kasus peradilan yang tumbuh dan hidup di masyarakat biasanya hanya menangani permasalah sederhana yang berkaitan dengan pengaturan vertikal, yaitu jika ada banding hanya ke pengadilan distrik. Masalah tersebut biasanya sederhana sekali lagi terkait dengan pengaturan vertikal yaitu jika ada banding hanya ke pengadilan distrik. Permasalahan tersebut hanya seputar bidang keluarga, seperti perceraian, hak asuh anak, pembagian kekayaan

\footnotetext{
${ }^{4}$ Rudolf Schlesinger, Comparative Law-Cases and Materials, (Brooklyn : Foundation Press, 1959), sebagaimana diutip oleh Romli Atmasasmita, Perbandingan Hukum Pidana, (Bandung: Mandar Maju, 2000), hlm. 7.

${ }^{5}$ Bagir Manan, Sistem Peradilan Berwibawa, Suatu Pencarian, Cetakan Pertama, (Yogyakarta: FH UII Press, 2005), hlm. 
bersama, atau warisan. Kasus perceraian dan hak asuh anak tidak perlu naik banding, hanya sampai pada pemeriksaan peradilan banding saja.

Dengan cara tersebut, setidaknya ada dua hal yang ingin dicapai yaitu;

1. Pencari keadilan dapat dengan cepat mengambil keputusan yang menggambarkan keadilan dan memiliki kekuatan hukum permanen (putusan dapat segera dilaksanakan).

2. Sebagai upaya mengurangi dan membatasi banding. Cara ini bisa menghindari penumpukan banding.

Indonesia juga memiliki beberapa pengadilan khusus di bawah pengadilan umum yaitu pengadilan niaga, pengadilan HAM ad hoc, Pengadilan Tindak Pidana korupsi, dan pengadilan hubungan industrial. Ada juga kekhususan dalam pemeriksaan kasus anak-anak yang diadili peradilan anak pada badan peradilan mulai dari pengadilan kabupaten dan kota hingga Mahkamah Agung. Namun, peradilan anak bukan pengadilan khusus atau berdiri sendiri. Kekhususan hanya pada hakim khusus yaitu hakim untuk memeriksa perkara anak-anak berdasarkan tugas dari ketua Mahkamah Agung dan prosedur pemeriksaan khusus yang berbeda dengan orang dewasa.

\section{Sistem Hukum dalam Struktur Pengadilan di Indonesia}

Bangsa Indonesia menggunakan sistem hukum dari peninggalan Belanda, ini terjadi karena penjajaan Belanda di Indonesia selama lebih dari tiga ratus tahun. Hukum perdata yang tiba di Indonesia saat ini masih menggunakan KUHPerdata peninggalan Belanda yang pada negara asalnya tidak dipergunakan lagi atau telah diganti. Pengaruh Belanda yang memiliki sistem hukum common law, menjadi sebab Indonesia membagi antara Hukum Publik dan Hukum Privat tetapi masih dalam satu atap Keadilan.

\section{Struktur Pengadilan di Indonesia}

Ada empat (4) pengadilan di Indonesia berdasarkan Pasal 24 ayat (2) UUD 1945, antara lain sebagai berikut:

1. Lingkungan Pengadilan Umum: mencakup perselisihan hukum perdata dan hukum pidana;

2. Lingkungan Pengadilan Agama: yang membawahi hukum bagi individu beragama Islam dibidang wakaf dan hukum keluarga serta permasalahan lain dibidang muamalah.

3. Lingkungan Pengadilan Administrasi: mencakup perselisihan antara individu yang merupaka warga negara dan pejabat administrasi Negara.

4. Lingkungan Pengadilan Militer: hanya mencakup kejahatan atau pelanggaran yang dilakukan oleh militer.

Pengadilan tersebut diatas secara struktur merupakan pengadilan tingkat pertama dan dapat diajukan upaya hukum kepada pengadilan tingkat selanjutnya serta pada akhirnya semuanya bermuara pada Mahkamah Agung (MA). Di bawah Mahkamah Agung ada Pengadilan Tinggi untuk Pengadilan Umum dan Pengadilan Agama di setiap ibukota provinsi, masing-masing berikut penjelasan:

1. Pengadilan umum disebut juga Pengadilan Negeri.

Peraturan perundang-undangan yang mengatur tentang pengadilan umum yang disebut juga Pengadilan Negeri adalah Undang-Undang Nomor 13 Tahun 1965 tentang Pengadilan dalam Lingkungan Peradilan Umum dan Mahkamah Agung. Pada Pengadilan Negeri yang merupakan pengadilan tingkat pertama, berwenang memutuskan perkara pidana dan perdata pada wilayah hukum setingkat kabupaten atau kota.

2. Pengadilan Agama (PA)

Hukum yang mengatur Pengadilan Agama yaitu Undang-Undang No. 7 tahun 1989 tentang Pengadilan Agama, tugas dan wewenang untuk memeriksa, memutuskan dan menyelesaikan tindakan hakim di tingkat pertama di antara orang-orang yang beragama Islam di bidang perkawinan, warisan, wasiat, hibah, wakaf dan shadaqoh, di mana seluruh bidang didasarkan pada hukum Islam. Pengadilan Agama bersifat pengadilan khusus untuk warga negara yang beragama Islam pada hal-hal terkait hubungan muamalah.

3. Pengadilan Tata Usaha Negara (TUN)

Pengadilan Tata Usaha Negara diatur Undang-Undang No. 5 tahun 1986 sebagaimana telah diubah dengan Undang-Undang No. 9 tahun 2004 tentang Pengadilan Tata Usaha Negara. Pengadilan Tata Usaha Negara (TUN) berwenang untuk menyelesaikan perselisihan antara warga negara dan Pejabat Administrasi Negara. Objek perkaranya adalah keputusan Pejabat Tata Usaha Negara terkait permasalahan administrasi dikeluarkan oleh pejabat administrasi negara. Dan di Pengadilan Tata Usaha Negara, ada 2 (dua) jenis pemulihan, antara lain, Upaya Administrasi, yang terdiri dari banding administratif dan keberatan, serta gugatan.

4. Pengadilan Militer (PM)

Pengadilan Militer diatur dalam Undang-Undang No. 31 tahun 1997 tentang Pengadilan Militer. Pengadilan ini berwenang untuk mengadili kejahatan atau pelanggaran yang dilakukan oleh anggota militer.

5. Pengadilan Khusus yang terdapat di Indonesia, Pengadilan Khusus di Indonesia masing-masing memiliki haknya sendiri, sebagaimana dijelaskan lebih lanjut di bawah ini, antara lain: 
a. Pengadilan Niaga dibuat dan dibentuk oleh Keputusan Presiden No. 97 tahun 1999. Kewenangan Pengadilan Niaga, antara lain, adalah untuk mendengarkan kasus Kepailitan, Hak Kekayaan Intelektual, serta perselisihan komersial lainnya yang ditentukan oleh Undang-Undang.

b. Pengadilan Hak Asasi Manusia dibentuk dan dibentuk oleh Undang-Undang No. 26 tahun 2000. Pengadilan Hak Asasi Manusia adalah untuk mengadili pelanggaran berat hak asasi manusia, seperti yang terjadi pada kasus-kasus pelanggaran HAM berat di Timor Timur dan Tanjung Priok pada tahun 1984. Manusia Bagian tengah pelanggaran hak asasi manusia mengeluarkan Keputusan Presiden No. 53 tahun 2001 tentang pembentukan Pengadilan Hak Asasi Manusia Ad Hoc di Pengadilan Negeri Jakarta Pusat, yang sekarang diamandemen dengan Keputusan Presiden No. 96 tahun 2001.

c. Peradilan Anak, dibentuk dan dibentuk oleh UU No. 3 tahun 1997, dimana implementasi CRC, yang disahkan, bahwa setiap anak berhak atas perlindungan, baik terhadap eksploitasi, pelecehan dan perlakuan buruk dalam proses peradilan pidana. Dan Yurisdiksi Peradilan Anak dalam kasus pidana adalah mereka yang berusia 8 tahun tetapi belum mencapai 18 tahun.

d. Pengadilan Pajak, dibentuk dan dibentuk oleh Undang-Undang Nomor 14 Tahun 2002, dan memiliki yurisdiksi untuk menyelesaikan sengketa di bidang perpajakan. Sengketa pajak itu sendiri adalah sengketa yang timbul di bidang perpajakan antara wajib pajak atau orang dalam pajak dan otoritas yang berwenang sebagai hasil dari penerbitan keputusan yang dapat diajukan banding atau naik banding ke Pengadilan Pajak berdasarkan hukum perpajakan, termasuk gugatan atas implementasi penagihan berdasarkan Undang-undang penagihan tagihan pajak.

e. Pengadilan Perikanan, dibentuk dan dibentuk oleh Undang-Undang 31 tahun 2004. Pengadilan ini memiliki wewenang untuk memeriksa, mengadili, dan memutuskan tindakan kriminal di bidang perikanan, dan beroperasi di dalam pengadilan umum dan memiliki yurisdiksi sesuai dengan hukum setempat pengadilan distrik yang bersangkutan.

f. Pengadilan Tipikor, dibentuk dan didirikan di bawah mandat Pasal 53 UU No. 30 tahun 2002 tentang Komisi Pemberantasan Korupsi. Pengadilan ini memiliki yurisdiksi untuk menangani kasus korupsi dan berdomisili di jakarta

\section{Sistem Hukum dalam Struktur Pengadilan di Malaysia}

Malaysia adalah negara bekas jajahan Inggris. Sebagai bekas jajahan Inggris, hukum Malaysia dipengaruhi oleh tradisi common law Inggris (Common Law System) dan Malaysia merupakan satu dari 53 (lima puluh tiga) negara anggota Persemakmuran Inggris.

Malaysia tidak meninggalkan atau merombak seluruh tatanan hukum dasar mereka yang telah berlaku jauh sebelum hukum Inggris menjadi tatanan hukum negara, hal itu disebabkan karena Malaysia ingin menjaga hukum sesuai dengan nilai-nilai yang ada dan hidup di masyarakat mereka. Sehingga dalam menciptakan kesadaran hukum akan lebih mudah tumbuh dan tercipta dari pada merombak total seluruh budaya hukum lama dengan budaya baru. Tradisi sistem hukum umum Inggris berdiri di tengah-tengah sistem hukum Islam (dilaksanakan oleh pengadilan atau Pengadilan Syariah) dan hukum adat dari berbagai kelompok masyarakat adat.

Sistem Peradilan di negara Malaysia dibagi dan disesuaikan dengan hukum yang dibuat tanpa menghilangkan sistem arbitrase sesuai dengan nilai-nilai yang ada di masyarakat mereka.

Sumber hukum Malaysia terdiri dari tiga, yaitu: hukum tertulis/nasional, hukum Islam dan hukum kebiasaan/adat. Hukum adat terdiri dari hukum Inggris dan aturan kesetaraan telah berkembang pengadilan Malaysia, di mana ada kemungkinan besar terjadi konflik dengan hukum tertulis. Adanya penyesuaian keberlakuan hukum dianggap sebagai solusi yang tepat untuk mengatasi konflik hukum.

Ada dua pengadilan tinggi, satu di Semenanjung Malaysia, yang dikenal sebagai Pengadilan Tinggi di Malaya, dan yang lainnya di Malaysia Timur, yang dikenal sebagai Pengadilan Tinggi di Sabah dan Sarawak. Dengan pengecualian semua masalah dalam yurisdiksi pengadilan Syariah, pengadilan ini memiliki yurisdiksi tidak terbatas untuk wilayah tersebut. Mereka juga dapat menerima banding dari the Sessions Court dan Putusan Pengadilan.

Posisi Pengadilan Tinggi di Malaysia memeriksa kasus-kasus serta tingkat banding pertama untuk the Sessions Court dan Putusan Pengadilan tingkat pertama. Struktur Peradilan di Malaysia adalah sebagai berikut

1. Pengadilan Banding

Beberapa Pengadilan Banding Malaysia yaitu Supreme Flirt dan Pengadilan Federal (Supreme Guild). Pengadilan Banding terdiri dari Ketua Pengadilan dan 10 (sepuluh) hakim. Wewenang Pengadilan Tinggi adalah untuk memeriksa banding pengadilan tinggi dan memiliki yurisdiksi lain sebagaimana ditentukan untuk hukum federal. Di Malaysia, Pengadilan Tinggi adalah pengadilan yang menilai putusan pengadilan tinggi. Di Indonesia, pengadilan Banding merujuk ke Pengadilan Tinggi. Sedangkan di Malaysia adalah pengadilan tingkat pertama dengan tingkat banding yang sama untuk Pengadilan Sidang dan Pengadilan Hakim

2. Pengadilan federal 
Pengadilan Federal terdiri dari hakim agung di pengadilan federal, presiden pengadilan banding, ketua hakim pengadilan tinggi, dan tujuh hakim lain yang ditunjuk oleh raja di bawah saran ketua pengadilan Pengadilan Federal.

Pengadilan Federal memiliki yurisdiksi untuk menentukan validitas suatu undang-undang dengan pertimbangan hal itu disebabkan masalah di luar wewenang parlemen dan undang-undang negara bagian dalam membuat undangundang. Nantinya, raja bisa mengajukan pertanyaan tentang dampak ketentuan hukum dari Pengadilan Federal.

Pengadilan Federal juga memiliki yurisdiksi untuk menentukan perselisihan antara negara dan federasi atau di negara bagian lain. Ketika pertanyaan tentang dampak undang-undang terhadap persidangan di pengadilan lain, Pengadilan Federal memiliki yurisdiksi untuk menentukan pertanyaan dan membatalkan kasus ke pengadilan lain sesuai dengan ketentuan Pengadilan Federal.

3. the Sessions Court

the Sessions Court memiliki yurisdiksi pidana untuk menuntut semua kejahatan yang tidak tersentuh oleh hukuman mati. Pengadilan ini juga memiliki yurisdiksi dalam kasus perdata yang berkaitan dengan kecelakaan kendaraan, kasus tuan tanah dengan penyewa dan kasus lainnya dengan jumlah kompensasi sekitar 250.000 ringgit, dan juga dapat memeriksa kasus dengan tuntutan lebih tinggi pada perjanjian dengan pihak terkait.

Namun, perselisihan sipil terkait dengan permintaannya untuk sesuatu, misalnya kontrak pembatalan, putusan pengadilan, keputusan deklaratif, atau pelaksanaan kepercayaan di luar yurisdiksi the Sessions Court.

4. Pengadilan Tingkat Pertama.

Pengadilan tingkat pertama memeriksa kasus-kasus pidana dengan hukuman terbatas pada 10 tahun penjara atau denda. Pengadilan ini dapat memutuskan hukuman penjara 5 tahun, denda $\$ 10.000$, hukuman cambuk sebanyak 12 kali, atau kombinasi ketiganya.

Pengadilan ini juga dapat memeriksa banding oleh Pengadilan Pengulu. Pengadilan Hakim memeriksa kasus perdata kelas dua dengan klaim sebesar 30.000 ringgit dan kasus pidana dengan hukuman penjara 12 bulan atau denda. Pengadilan ini dapat memberikan hukuman penjara hingga 6 bulan, denda 1.000 ringgit, atau kombinasi dari kedua hukuman ini.

5. Pengadilan Pengulu

Pengadilan Pengulu ditemukan di Malaysia Barat dan menangani kasus-kasus yang melibatkan pihak-pihak warga negara Asia yang menggunakan dan memahami bahasa Melayu. Pengadilan-pengadilan ini juga menangani perkara perdata dengan klaim 50 ringgit dan pelanggaran ringan dengan denda maksimum denda 25 ringgit.

6. Pengadilan remaja (pengadilan Anak)

Kejahatan yang dilakukan oleh kelompok remaja (antara usia 10 hingga 18 tahun) diadili oleh pengadilan remaja, kecuali berat kejahatan yang dilakukan. Ini terdiri dari dua penasihat (salah satunya, jika mungkin perempuan). Hakim memutuskan suatu kasus dan penasihat hanya memberikan nasihat tentang hukuman. Hukuman penjara adalah pilihan terakhir dibandingkan dengan pengiriman ke sekolah khusus yang telah ditentukan.

7. Pengadilan syariah

Pengadilan syariah adalah pengadilan di negara bagian yang agak terpisah dari pengadilan federal, yang tidak memiliki yurisdiksi di pengadilan Syariah. Dengan kata lain, bahwa pengadilan federal tidak memiliki yurisdiksi dalam kasus-kasus syariah di bawah otoritas pengadilan syariah.

\section{SIMPULAN}

Dengan melihat sistem hukum Malaysia, faktanya, Indonesia tidak lebih buruk daripada di Malaysia, bahkan Indonesia memiliki banyak keunggulan yaitu orang yang kompeten di bidang hukum, dan oleh karena itu kemungkinan penyebab hukum di Indonesia masih senonoh karena banyak orang yang jangan menuruti hukum. Jangan menutup mata jika sistem hukum yang diterapkan Negara Malaysia kemungkinan akan meningkatkan sistem hukum yang ada di Indonesia.

Menurut Friedman, jika menginginkan undang-undang yang lebih baik, penegakan hukum harus memenuhi tiga komponen: struktur yang melihat bagaimana sistem hukum menyediakan layanan untuk penanaman bahan hukum secara teratur. Substansi adalah melihat output dari sistem hukum dalam bentuk peraturan dan keputusan. Budaya melihat hukum terdiri dari nilai-nilai yang ada di masyarakat yang sangat berpengaruh dalam kerja hukum. Negara harus menciptakan sistem hukum yang baik, struktur pengadilan harus mempertimbangkan budaya masyarakat seperti Malaysia, karena orang akan lebih patuh jika hukum tersebut digunakan sesuai dengan nilai-nilai yang telah tertanam dan mendarah daging di dalamnya.

Di Negara Malaysia, Yurisdiksi dalam hukum pidana terbatas pada apa yang sudah ada di pengadilan federal dan terbatas pada Muslim yang melanggar hukum Syariah di mana pelaku dapat dihukum hingga tiga tahun penjara dan denda 5.000 ringgit, hukuman cambuk maksimal 6 kali, atau kombinasi dua atau lebih.

1. Pengadilan asli 
Di Sabah dan Sarawak, hukum umum digunakan di pengadilan asli. Yurisdiksi yang berlaku antara pengadilan di pengadilan yang berbeda di Sabah dan Sarawak, tetapi umumnya meluas ke situasi di mana kedua belah pihak merupakan kelompok adat; kasus memeriksa masalah agama, seksualitas, atau perkawinan di mana satu pihak adalah penduduk asli; dan kasus-kasus lain di mana yurisdiksi diatur oleh hukum tertulis. Niat pengadilan pribumi adalah pengadilan adat yang berlaku untuk masyarakat di Sabah dan Sarawak.

2. Pengadilan lain

Selain itu ada juga pengadilan militer yang menangani orang-orang yang terlibat dalam kegiatan militer. Pengadilan ini tidak memiliki masalah hukum perdata yurisdiksi yang berkaitan dengan warga negara atau personil militer, dan tidak memiliki yurisdiksi pidana atas warga negara. Menteri yang bertanggung jawab atas undangundang hubungan industrial dapat mengajukan perselisihan antara penyedia pekerjaan dengan serikat pekerja di pengadilan industri, dan direktur jenderal pekerja dapat dipanggil untuk menyelesaikan perselisihan mengenai gaji karyawan.

Banyak undang-undang yang menyediakan arbitrase, arbitrase, legislasi berikutnya pada tahun 1952 yang menyediakan aturan untuk arbitrase domestik. Ada juga Pusat Regional untuk Arbitrase di Kuala Lumpur yang menyediakan fasilitas untuk melaksanakan arbitrase pada transaksi komersial internasional.

\section{DAFTAR PUSTAKA}

Bagir Manan, 2005, Sistim Peradilan Berwibawa: Suatu Pencarian, FH UII Press, Yogyakarta

De Cruz, Peter, 2010, Perbandingan Sistem Hukum, Common Law, Civil Law dan Socialist Law, Nusa Media, Bandung.

M. Yahya Harahap, 1997, Beberapa Tinjauan Mengenai Sistem Peradilan dan Penyelesaian Sengketa, PT. Citra Aditya Bakti, Bandung.

Munir Fuady, 2010, Perbandingan Ilmu Hukum, Refika Aditama, Bandung.

Rudolf D Schlesinger, 1959, Comparative Law-Cases and Materials, Foundation Press, Brooklyn.

Satjipto Rahardjo, 2008, Negara Hukum yang Membahagiakan Rakyatnya, Genta Press, Yogyakarta.

Satjipto Rahardjo, 2009, Lapisan-Lapisan dalam Studi Hukum, Bayumedia Publishing, Malang.

Soerjono Soekanto, 1989, Perbandingan Hukum, Citra Aditya Bakti, Bandung.

Tresna, 1957, Peradilan di Indonesia dari abad ke abad, W. Versluys N.V., Jakarta.

Warassih, Esmi, 2010, Peranata hukum sebagai telaah sosiologis, Badan Penerbit Universitas Diponegoro, Semarang. 